\title{
Microbiological profile and antimicrobial susceptibility in children with perforated appendicitis at Dr. Sardjito General Hospital, Yogyakarta
}

\author{
Andi Dwihantoro ${ }^{1}$ and Rochadi ${ }^{*}$ \\ ${ }^{1}$ Pediatric Surgery Division, Department of Surgery, Faculty of Medicine, Universitas \\ Gadjah Mada /Dr. Sardjito General Hospital, Yogyakarta
}

DOI: http://dx.doi.org/10.19106/JMedSci004801201604

\begin{abstract}
Acute appendicitis is the most common surgical cause of acute abdominal pain in children. Perforated appendicitis is the major complication of acute appendicitis with incidence in children of $30-40 \%$. Perforated appendicitis should be operated immediately along with the administration of broad-spectrum antibiotics. The aim of this study isto analyze the microbiological profile and determine the antimicrobial susceptibility in children with perforated appendicitis at Dr. Sardjito General Hospital, Yogyakarta, Indonesia.We analyzed the pus from the perforated appendicitis patients who underwent surgery at Dr. SardjitoGeneral Hospital from January 2005 to September 2009. Escherichia coli (43\%) was the most common aerobic bacteria found in children with perforated appendicitis, followed by Pseudomonas aeruginosa (26\%), Klebsiellapneumonia (11\%), Streptococcus $(11 \%)$, and Proteus mirabilis $(3 \%)$.The most sensitive antibiotics were imipenem, phosphomycin, amikacin and netilmicin, followed by the $4^{\text {th }}$ and the $3^{\text {rd }}$ generation of cephalosporin, amoxicillin, ampicillin, and trimethoprim/sulfamethoxazole. In addition, there was no statistically significant difference in terms of resistant and sensitivity between the $4^{\text {th }}$ generation cephalosporin compared to phosphomycin, netilmicin, or imipenem $(p>0.05)$. In conclusion, the most common bacteria found in perforated appendicitis in Dr. Sardjito General Hospital is E.coli. The administration of the $4^{\text {th }}$ generation of cephalosporin might be appropriate for the children with perforated appendicitis.
\end{abstract}

\section{ABSTRAK}

Appendisitis adalah penyebab terbanyak akut abdomen yang memerlukan pembedahan pada anak. Komplikasi apendisitis adalah perforasi dan insidensinya pada anak 30-40\%. Terapi apendisitis perforasi yaitu operasi segera dengan pemberian antibiotica berspektrum luas. Tujuan penelitian adalah untuk menganalisis profil mikrobiologi apensitis perforasi dan menentukan sensitivitas antibiotic pada anak dengan apendisitis perforasi di RumahSakit Umum Pusat Dr. Sardjito, Yogyakarta, Indonesia. Subjek penelitian adalah bakteri aerob hasil isolasi pus cavum peritoneum/intraperitoneal pasien apendisitis perforasi anak yang dioperasi di RSUP Dr. Sardjito Yogyakarta Januari 2005 - September 2009. Ditemukan bakteri aerob terbanyak pada pasien apendisitis perforasi anak adalah E.coli, kemudian $P$. aeruginosa, Kl. pneumonia, Streptococcus, dan P. mirabilis. Antibiotika paling sensitif; imipenem, fosfomisin, amikasin, dan netilmisin; diikuti sefalosporin generasi 4 dan 3, amoksisilin, ampisilin, trimetoprim/sulfametoksazol. Tidak ada perbedaan secara nyata 
dalam hal resistensi dan sensitivitas antara sefalosporin generasi ke-4 dibandingkan dengan fosfomycin, netilmisin, atau imipenem $(p>0,05)$. Kesimpulannya, bakteri yang paling sering umum pada apendisitis perforasi anak di RSUP Dr. Sardito, Yogyakarta adalah E. coli. Terapi dengan antibiotic cephalosporin generasi ke-4 tepat untuk anak-anak dengan apendisitis perforasi.

Keywords: microbiological profile - antimicrobial susceptibility - perforated appendicitis -children - Indonesia

\section{INTRODUCTION}

Acute appendicitis is the most common surgical cause of acute abdominal pain in adult and children and is one third of acute abdominal pain requiring inpatient care. ${ }^{1}$ The risk of getting appendicitis in children aged 1 to 14 years is $7 \%$. In United States, more than 70,000 cases of appendicitisa year or about 1 child in every 1000 children were reported. ${ }^{2,3}$ The incidence of appendicitis is rare in children under the age of 1 year, however it is increased in older children aged 6-10 years. The peak appendicitis incidence is observed in children aged 12 years or adolescence. ${ }^{4}$

Perforated appendicitis is a complication caused by appendicitis resulting local or general peritonitis. ${ }^{1,2,5}$ The incidence of perforated appendicitis in children is around $30-40 \%$, whereas in preschool children range from 60 to $65 \%$. The incidence of perforated appendicitisin children aged less than 2 year is lower $(2 \%)$, however the risk of getting perforated is higher (95\%). ${ }^{3}$ Multiethnic study in 53,555 appendicitis cases in US children showed that $63.5 \%$ perforated appendicitis and $36.5 \%$ simple appendicitis. ${ }^{6}$

The symptoms of appendicitis in children are not specific, of whom the early symptoms are crying and loss of appetite. Children usually could not describe the pain. A few hours later the child will show nausea and vomiting, then becomes fatigue and lethargic. Because the symptoms are not specific, often diagnosed after perforation occurs. Perforated appendicitis in children occur because their appendix have thin wall, their omentum has not well developed, yetand the children is unable to describe the pain thereby extending the time of diagnosis in which results in late diagnosis. ${ }^{7}$ The prolonged diagnosis of appendicitis will cause perforation and all other complications. ${ }^{8}$ Perforated appendicitis patients will experience more pain and dehydration than the patients with simple acute appendicitis. If the perforated appendicitis getting worse, severe complications such as sepsis, multisystem organ failure, and death will occur. ${ }^{1}$

Perforated appendicitis should be operated immediately along with the administration of wide-spectrum antibiotics. ${ }^{8,9}$ Antibiotics regimen should be appropriate and effective against the gastrointestinal tract microorganisms. There are several bacteria such as anaerobic bacteria Bacteroides, Clostridia, and Peptostreptococcussp; aerobic gram-negative bacteria such as Escherichia coli, Pseudomonas aeruginosa, Enterobacter and Klebsiellasp; and few gram-positive bacteria. ${ }^{1}$ Eschericia coli and Bacteroidesfragilisare two most common microorganism found in perforated appendicitis. ${ }^{2}$ Moreover, E. coliand P.aeruginosa are the most common aerobic gram-negative bacteria causing severe sepsis. ${ }^{10}$ Until now, duration of antibiotic use and antibiotic regiments remains controversial. The use of antibiotics for appendicitis treatment is vary among pediatric surgeons ${ }^{3}$ Drug of choice 
for appendicitis and its complications are intravenous ampicillin, gentamycin, and clindamycin or metronidazole. ${ }^{1,3}$

Problem that may arise in the treatment of perforated appendicitis is bacterial resistant to antibiotics. Bacterial resistantagainstantibiotic could impacts on morbidity and mortality. Antibiotic Resistant Microorganisms (ARM) is a major factor in morbidity and mortality. These have consequences in highsocial and economic cost. ${ }^{11}$ Recent study conducted in Barnes-Jewish Teaching Hospital's ICU, St. Louis found that antibiotics in approximately $8.5 \%$ of patients treated in the ICU classified as inadequate. Of the overall antibiotics that are classified as inadequate, $45.2 \%$ was found in patients suffered with nosocomial infections during hospitalized. The mortality rate of patients due to inadequate antibiotic treatment was $52.1 \%$, significantly higher than patients who received antibiotics adequately(12.2\%). ${ }^{11}$

Recently, the use of cephalosporin class antibiotics along with metronidazole has been used as a drug of choice in patients with perforated appendicitis in Department of Pediatric Surgery, Dr. Sardjito General Hospital/Faculty of Medicine, Universitas Gadjah Mada, Yogyakarta, Indonesia. However, the use of the antibiotics in the hospital has not ever been evaluated. The study was conducted to evaluate the microbiological profile of perforated appendicitis and to determine the antimicrobial susceptibility in children with perforated appendicitis at the Dr. Sardjito General Hospital.

\section{MATERIALS AND METHODS}

\section{Patients}

This study was a cross-sectional observational study involving children with perforated appendicitis who underwent surgery at the Department of Pediatric Surgery,
Dr. Sardjito General Hospital, Yogyakarta during January, 2005 to September, 2009.We ascertained subjects who fulfill the following criteria: patients who have grade 3 , grade 4, and grade 5 of acute appendicitis according to Cloud Classification; children aged 1-16 years; subjects who had been examined for pus culture and bacteria sensitivity test; pus originated from peritoneal cavity pus and by the time had not been administered antibiotic yet. The protocol of this study was approved by the Medical and Health Research Ethics Committee, Faculty of Medicine, Universitas Gadjah Mada, Yogyakarta.

\section{Procedure}

The children who visited at Department of Pediatric Surgery, Dr. Sardjito General Hospital, Yogyakarta with suspect appendicitis were selected. The diagnosis of perforated appendicitis was performed based on history, physical examination, and blood tests. Abdominal radiography such as ultrasound or X-ray of the abdomen was conducted if the diagnosis was doubtful. Pus samples were collected from peritoneal cavity on patients who underwent surgery, using sterile syringe, then sent to Clinical Microbiology Division of Clinical Pathology Laboratory, Dr. Sardjito General Hospital to perform the bacterial culture and sensitivity.

The pus was cultured directly onto blood agar in order to obtain Gram-negative bacteria and MacConkey agar to obtain Gram-positive bacteria. The plates were incubated aerobically and anaerobically and were examined at 24 and 48 hours. All bacteria isolated were identified by routine laboratory methods and antibiotic sensitivities were carried out by the disc technique.

\section{Data analysis}


Data of acute appendicitis distribution according to Cloud classification and age, microbiological profile, profile of sensitivity test of bacteria, frequency of bacteria according to sensitivity tests were presented as percentage. The differences in sensitivity to antibiotics among bacteria tested were analyzed by Chi-square.A $p$ value less than 0.05 was considered as statistical significant.

\section{RESULTS}

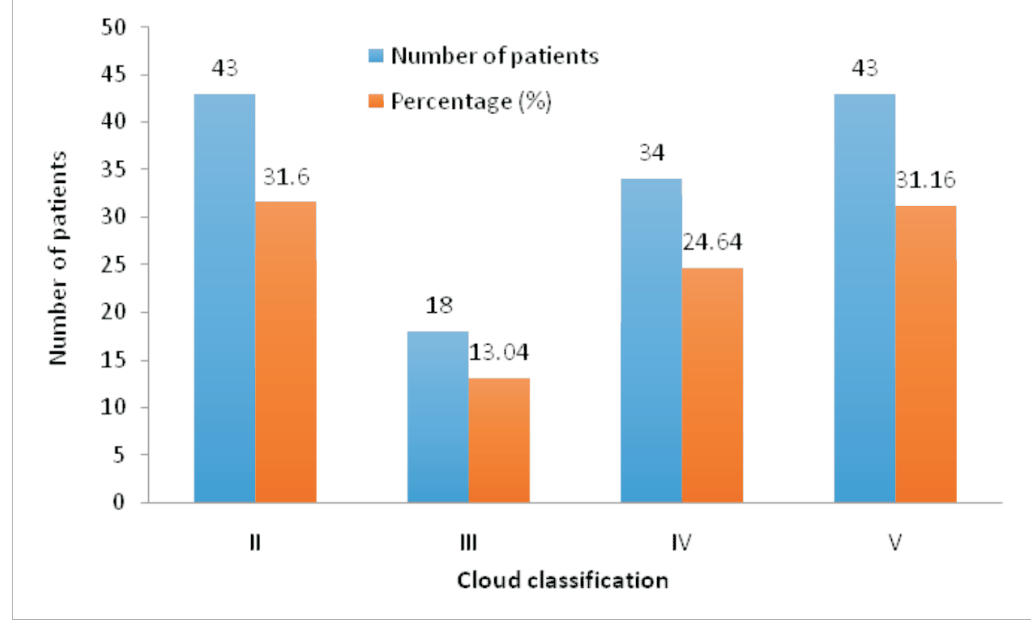

FIGURE 1. Distribution of acute appendicitis according to Cloud classification.

The mean of patient's age at operation was 8.7 years, with the most common operation age
During January, 2005 to September, 2009, a total 138 subjects who fulfilled the inclusion criteria for this study. There were 82 (59.4\%) male patients and $56(40.58 \%)$ female patients. According to Cloud Classification, there were $43(31.16 \%)$ patients classified as grade II and grade V, 34 patients $(24.64 \%)$ classified as grade IV, 18 patients (13.04\%) classified as grade III (FIGURE 1). In addition, 43 patients $(31.16 \%)$ were classified as simple appendicitis and 95 patients $(68.64 \%)$ patients were classified as complicated or perforated appendicitis. 


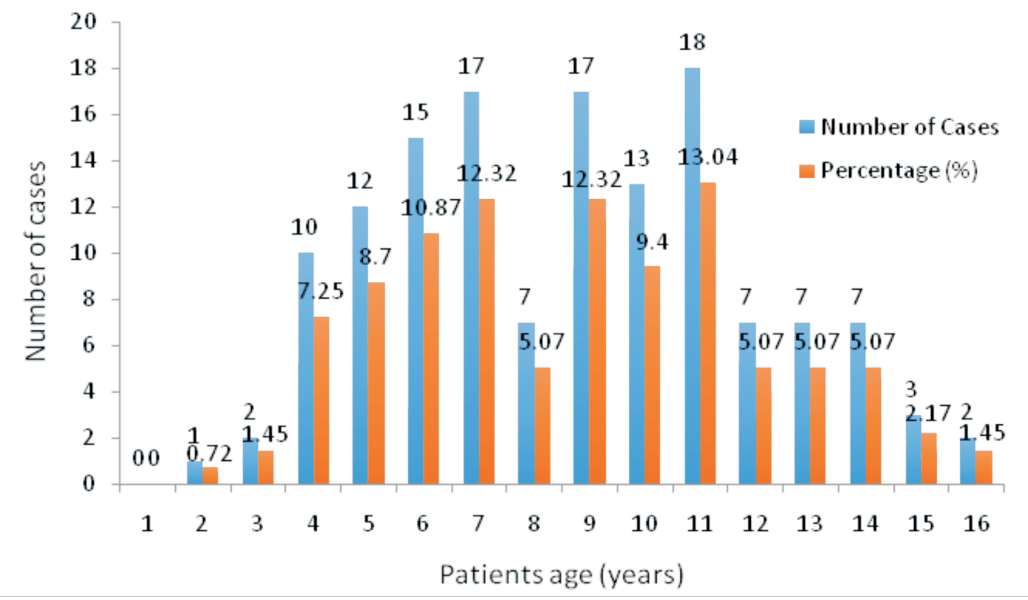

FIGURE 2. Distribution of acute appendicitis according to age at operation.

We performed pus culture from peritoneal cavity in 95 patients with perforated appendicitis and 38 isolated bacteria was obtained to be conducted a sensitivity test.The most common aerobic bacteria found was E. coli (43\%), followed by Pseudomonas (26\%), K. pneumonia and Streptococcus (11\%) (FIGURE 3).

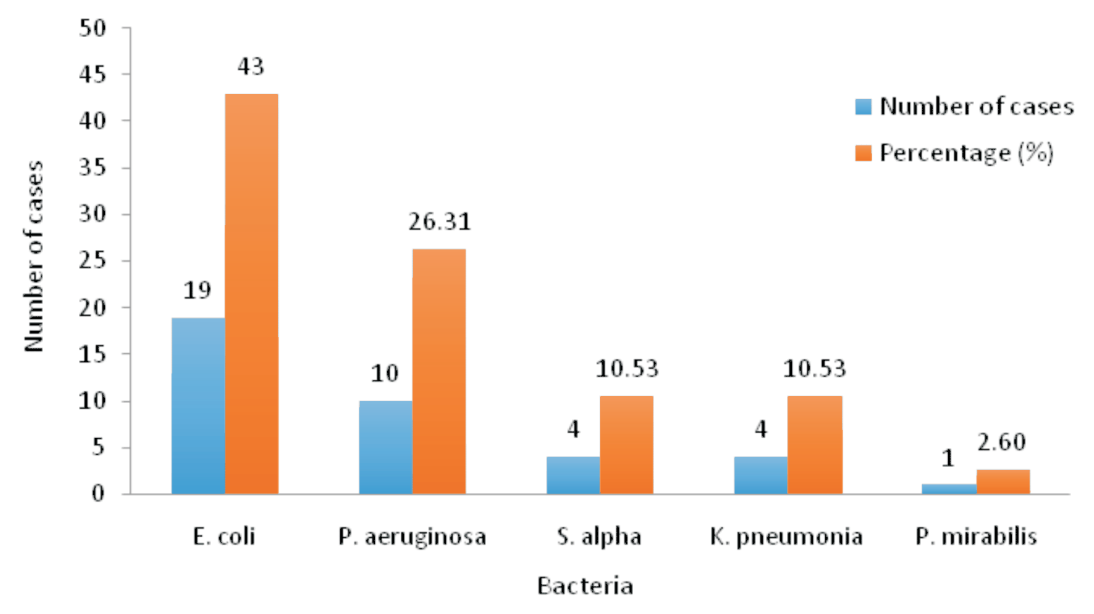

FIGURE 3. Microbiological profile from intraperitoneal pus in perforated appendicitis patients.

The sensitivity test showed that there were $8.6 \%$ cefepime resistant bacteria, $13.5 \%$ cefotaxime resistant bacteria, $13.9 \%$ ceftriaxone resistant bacteria; $16.7 \%$ ceftazidime resistant bacteria; $18.6 \%$ cefpirome resistant bacteria; $20 \%$ cefuroxime resistant bacteria; and 50\% cefalotina resistant bacteria (FIGURE 4). 


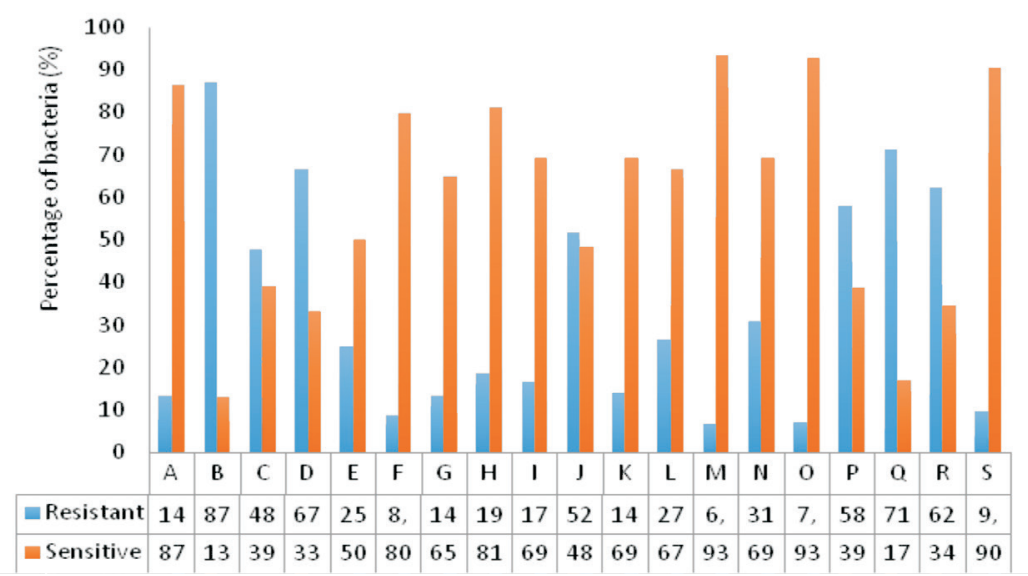

A:amikacin, B:ampicillin, C:ampicillin/sulbactam; D:amoxicillin; E: amoxicillin+ clavulanic acid; F: cefepime; G: cefotaxime; H:cefpirome; I: ceftazidime; J: chloramphenicol; K: ceftriaxone; L:ciprofloxacin; M: fosfomycin; N: gentamycin; O: imipenem; P: sulfamethoxazole; Q: tetracycline; R: trimethoprim; S: netilmicin

FIGURE 4. Profile of sensitivity test of bacteria isolated from peritoneal cavity pus in perforated appendicitis patients

Furthermore, there was no statistically significant difference among aerobic bacteria for sensitivity tests $(\mathrm{p}>0.05)$. In addition, there was no statistically significant difference between the 4th generation cephalosporin and phosphomycin, netilmicin, or imipenem for sensitivity test $(\mathrm{p}>0.05)$. However, there was a statistically significant difference between the 4th generation cephalosporin and the 3rd generation cephalosporin for sensitivity test $(\mathrm{p}<0.05)$ (FIGURE 5).

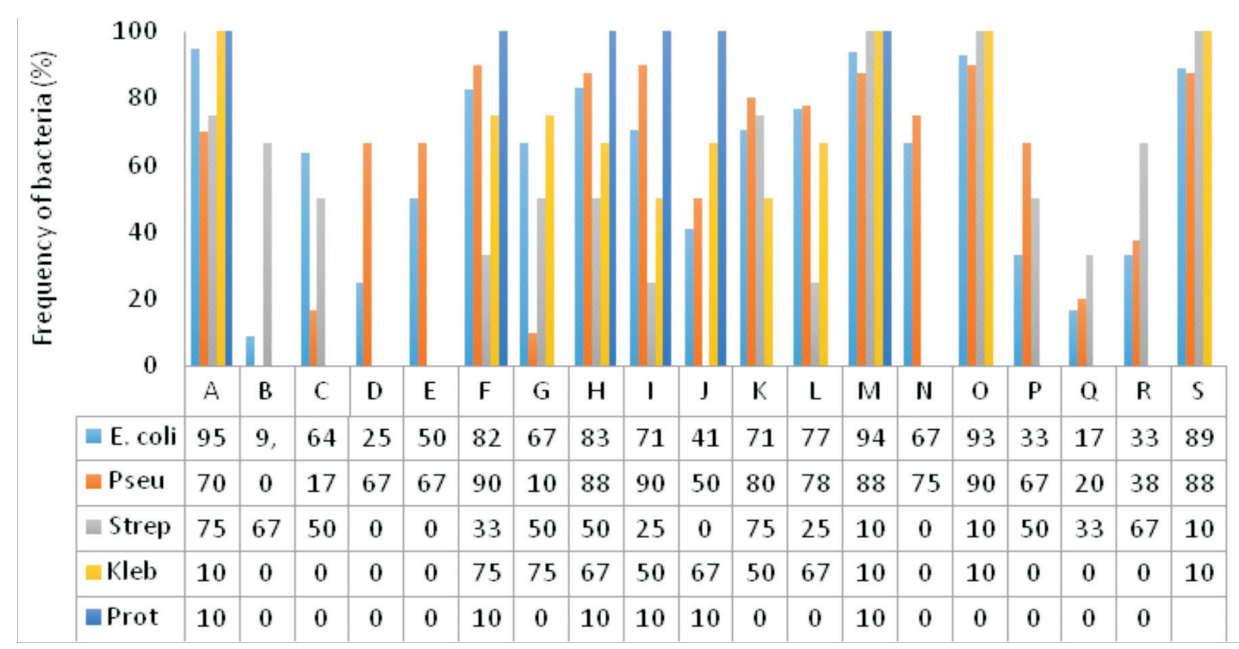

A:amikacin, B:ampicillin, C:ampicillin/sulbactam; D:amoxicillin; E: amoxicillin+clavulanic acid; F: cefepime; G: cefotaxime; H:cefpirome; I: ceftazidime; J: chloramphenicol; K: ceftriaxone; L:ciprofloxacin; M: fosfomycin; N: gentamycin; O: imipenem; P: sulfamethoxazole; Q: tetracycline; R: trimethoprim; S: netilmicin

FIGURE 5. Frequency of bacteria according to their sensitivity tests 


\section{DISCUSSION}

This study showed that the frequency of perforated appendicitis in children $(68.64 \%)$ was higher compared to previous study conducted by Stevenson ${ }^{2}$ who reported that the frequency of perforated appendicitis in children is $30-40 \%$. However, the number of perforated appendicitis incidence in preschool children is $60-65 \%$, whereas in children aged less than 2 year was $2 \%$, but the risk of getting perforated is higher than $95 \% .{ }^{2}$ Riwanto $^{7}$ and Kozar\& Roslyn ${ }^{9}$ revealed thatperforated appendicitis in children occurs because the thin wall of appendix, the undeveloped omentum so the protecting mechanism is not well developed or the child is not able to describe the pain thereby extending the time of diagnosis in which results in late diagnosis. It is similar in which $\mathrm{Kartono}^{8}$ mentioned that late diagnosis contributes to complicated perforation with all its consequences. Claud ${ }^{12}$ and Hartman ${ }^{13}$ reported that appendicitis is rare in children aged less than 1 year, but the incidence is increased in older children, with an average incidence in children aged 6-10 years, and the peak incidence in children aged 12 years or adolescence. This trend is similar to our study.

Morrow and Newman ${ }^{1}$ reported that in addition to perforated appendicitis anaerobic bacteria such as Bacteroides, Clostridia, Preptostreptococcussp, aerobic gramnegative bacteria can also be found such as E. coli, P. aeruginosa, Enterobacter and Klebsiella, and some gram-positive bacteria. Stevenson $^{2}$ reported that E. coli is one of the most common microorganism found in perforated appendicitis. Aribowo ${ }^{14}$ reported that E. coli and Klebsiella sp. are the most common pathogen of perforated appendicitis. Furthermore, Brooks et al..$^{10}$ reported that $E$. coli and P.aeruginosa are the most common aerobic gram-negative bacteria causing severe and fatal sepsis if they enter bloodstreams and often causing nosocomial infection as well.It was found in this study that the second most common bacteria is $P$. aeruginosa. In contrast, previous study in the same hospital foundthe second most common bacteri is Klebsiella $(22.54 \%)$, followed by Streptococcus (14.29\%), Enterobacter $(4.08 \%)$, and the least is Pseudomonas $(2.04 \%) .{ }^{14}$ The increase number $P$. aeruginosa infections indicates the change in the pattern of bacteria infection in children with perforated appendicitis in the Dr. Sardjito General Hospital. Brookset al. ${ }^{10}$ reported the state of the possible existence of nosocomial infection due to $P$. aeruginosais becoming widespread. Pseudomonas aeruginosa present in small amounts as normal flora of intestinal and skin that can cause illness even severe sepsis when it enters bloodstream and the body's immunity decreased. Moreover, Schwartz ${ }^{15}$ and Claud ${ }^{12}$ clearly state that the growth of appendix flora may change after the administration of antibiotics before or following laparotomy.

Cefepime and cefpirome are $4^{\text {th }}$ generation of cephalosporin, while ceftriaxone and ceftazidime are $3^{\text {rd }}$ generation of cephalosporin, cefuroxime is $2^{\text {nd }}$ generation of cephalosporin and cefalotin is $2^{\text {nd }}$ generation of cephalosporin. ${ }^{10}$ Cephalosporin has been widely used in clinical setting to treat various kinds of infection. The irrational use of the cephalosporin might increase the resistance of microorganisms to those antibiotics. In this study, between 8.6 to $20 \%$ of bacteria were found to be resistance to cephalosporins.

Cephalosporins are bactericidal and have the same mode of action as other $\beta$-lactam antibiotics (such as penicillins), but are less susceptible to $\beta$-lactamases. Cephalosporins disrupt the synthesis of the peptido glycan layer forming the bacterial cell wall. The 
peptidoglycan layer is important for cell wall structural integrity. The final transpeptidation step in the synthesis of the peptidoglycan is facilitated by transpeptidases known as penicillin-binding proteins (PBPs). Penicillinbinding proteins bind to the D-Ala-D-Ala at the end of muropeptides (peptidoglycan precursors) to crosslink the peptidoglycan. $\beta$-Lactam antibiotics mimic the D-Ala-DAla site, thereby irreversibly inhibiting PBP crosslinking of peptidoglycan. ${ }^{16}$

This study showed the common oral antibiotic thatbeenwidelyusedinthecommunity are amoxicillin, ampicillin, trimethropim/ sulphametoxazole, and tetracyclin. Most of them were resistant to specific isolated bacteria with $25-87 \%$ resistant percentage. Other antibiotics such as imipenem, phosphomycin, and netilmicin had low resistant percentage $(<10 \%)$ and high sensitivity ( $>90 \%)$, as well as in amikacin (86.5\%).Imipenem, phosphomycin, amikacin, and gentamicin had higher sensitivity percentage $(>90 \%)$ against those mentioned bacteria, followed by $4^{\text {th }}$ generation cephalosporin, and $3^{\text {rd }}$ generation cephalosporin. Otherwise, antibiotics in which had already been used commonly in the community had low sensitivity against those mentioned bacteria.

Our study is similar to previous study conducted by Aribowo in the same hospital. ${ }^{14}$ This author reported among 44 cases of adult acute appendicitis operated from January to June 2001, appendix fluid test showed $77 \%$ E.coli bacteria resistant to ampicillin, $81.8 \%$ Klebsiella resistant to ampicillin, and 57.4\% Streptococcus resistant to ampicillin. Whereas, Baskoro ${ }^{17}$ conducted a study on bacterial culture and sensitivity of peritoneal fluid in peritonitis patients who underwent exploratory laparotomy surgery during 2004 and found that the most sensitive antibiotics against aerobic bacteria are ceftriaxone
(87.1\%), ampicillin (19,1\%), and gentamicin $(58.1 \%)$.

However, theresults of this study showed different with the results reported by Donald et $a l .{ }^{18}$ The authorsreported that among 66 children who underwent surgery for perforated appendicitis, the administration of oral trimethoprim/sulphamethoxazole and metronidazole immediately after surgery (sufficient oral intake, afebrile, and normal leukocytes count), was only obtained 3 patients $(4.4 \%)$ suffered from surgical wound infections, and the rest remained afebrile and had normal leukocytes count. The authors suggested the administration of oral antibiotic trimethoprim/sulfamethoxazole and metronidazole immediately after surgery as long as the patients have sufficient oral intake, afebrile, and normal leukocytes are safe in pediatric patients with perforated appendicitis.

Cephalosporin has been widely used as a drug of choice in intra-abdominal infections, such as appendicitis. However, there are some experts who do not use it instead still choose 'triple' traditional antibiotics. Dunn $^{3}$ stated that the gold standard antibiotic for complicated appendicitis in his institution are an intravenous antibiotic of ampicillin, gentamicin, and clindamycin or metronidazole, while the combinations effectiveness of other antibiotics are still in empirical studies. However, Dunn ${ }^{3}$ mentioned that some combination of other antibiotics were also effective, including cefotaximeclindamycin, cefoxitin, clindamycin-amikacin, clindamycin-aztreonam, cefepimemetronidazole, ticarcillin-clavulanate and piperacillin-tazobactam. Other experts have similar opinion. Morrow and Newman ${ }^{1}$ stated that most of surgeons tends to choose 'triple' traditional antibiotics (ampicillin, gentamycin and clindamycin or metronidazole) or combination clavulanate added with gentamycin. Other study claimed that ticarcillin- 
clavulanate added with gentamicin proved to be more superior than ampicillin-gentamicinclindamycin in reducing length of stay, duration of fever and other complications. Another study found that there was the same effectiveness and efficacy in the use of piperacillin-tazobactam compared to 'triple' antibiotics in perforated appendicitis. Brooks ${ }^{10}$ study's stated that there is no specific treatment for Enterobacteriaceae. Ampicillin, cephalosporins, and aminoglycosides had greater sensitivity, but the sensitivity is very different for each bacterial strain so that it required a test for antibiotic sensitivity. Drug resistant is very common. Usually it is caused by a genetic mutation of bacteria. Any infection that is suspected due to $P$. aeruginosa should not be treated with a single antibiotic, because the success rate is low and the bacteria that can quickly develop drug resistant due to the use of a single antibiotic. Penicillins such as ticarcillin or piperacillin could be used in combination with tobramycin. Other drugs such as aztreonam, imipenem and quinolones, and the latest cephalosporins such as ceftazidime and cepoferazone could also be used against $P$. aeruginosa.

The $3^{\text {rd }}$ generation cephalosporin class of antibiotics such as cefotaxime and ceftriaxone along with metronidazole has been used as a drug of choice in patients with perforated appendicitis in Pediatric Surgery ward of Dr. Sardjito General Hospital. Although the action of these antibiotics work in accordance with the pattern of the bacteria obtained from the research, the majority $(90 \%)$ of gramnegative, the use of these therapies should be evaluated strictly considering the sensitivity percentage that is only $70 \%$. The $4^{\text {th }}$ generation cephalosporin such as cefepime and cefpirome could be used as a therapeutic option in perforated appendicitis in children in Dr. Sarjito General Hospital Yogyakarta, however, it does not rule out the possibility of resistant patterns that will continue to grow. The use of imipenem, phosphomycin, and gentamicin therapy may be an alternative therapy if the bacteria is resistant to all cephalosporins, and has no clinically improved or develop severe sepsis, based on the principles of rationality of antibiotic therapies such as bacterial sensitivity test. Imipenem that is derived from thienamicin antibiotic is produced by Streptomyces cattleya, is a bactericidal antibiotic against almost all gram-positive, gram-negative, both aerobic and anaerobic, especially against Pseudomonas bacteria. ${ }^{19}$

Bacterial resistant to antibiotics may have an impact on morbidity and mortality. Microorganisms that are resistant to antibiotics have become the main factor of the mortality and morbidity. These have consequences in highsocial and economic cost. ${ }^{11}$ The use of antibiotic need to be updated in accordance with the new evidence available and valid.

\section{CONCLUSION}

The most common bacteria found in perforated appendicitis in Dr. Sardjito General Hospital, Yogyakarta, Indonesia is $E$. coli. The administration of the $4^{\text {th }}$ generation of cephalosporin might be appropriate for children with perforated appendicitis in the hospital.

\section{ACKNOWLEDGEMENTS}

We would like to thank all patients who have participated in this study.

\section{REFERENCES}

1. Morrow SE \& Newman KD. Appendicitis. In: Ashcraft KW, Holcomb GW III, Murphy JP, editors. Pediatric surgery, 4th ed. Philadelpia: Elsevier Saunders Company, 2005. 
2. StevensonR.Appendicitis.In: Ziegler $\mathrm{M}$, Azizkhan R, Weber T, editors. Operative pediatric surgery. New York: McGraw Hill, 2003.

3. Dunn JCY. Appendicitis. In: O'Neill, JA, Coran AG, Fonkalsrud E, Grosfeld JL, editors. Pediatric surgery, 6th ed. Maryland Heights, 2006.

http://dx.doi.org/10.1016/B978-0-32302842-4.50101-7

4. HartmanGE. Acuteappendicitis.In: Behrman RE, Kliegman RM, Jenson HB editors. Nelson textbook ofpediatrics, 17th ed. New York: W.BSaunders Company, 2004.

5. Kartono D. Apendisitsakut. Dalam: Kumpulan KuliahIlmuBedah. Jakarta: BagianIlmuBedah FK UI/RSCM, 1995.

6. Jablonski KA, Gualirdo MF. Pediatric appendicitis rupture rate: a national indicator of disparities in health care access. Popul Health Metr 2005; 3(1):4. http:dx.doi. org/10.1186/148- 7954-3-4

7. Riwanto I, Hamami AH, Pieter J, Tjambolang T, Ahmadsyah I. Usushalus, apendiks, kolon, dananorektum. Dalam :Sjamsuhidajat R danWim de Jong editor. Buku ajar ilmubedah, ed. 2. Jakarta: Penerbbit EGC, 2005.

8. Kartono D., 1995. Apendisitisakut. Dalam: Soelarto R, editor. Kumpulan kuliah ilmu bedah. Jakarta: BagianIlmuBedah FK UI/ RSCM, 1995.

9. Kozar RA, Roslyn JJ. The appendix. In: SchwartzSI, Shires GT and Spencer FC, eds. Principles of surgery, 7th ed. New York: McGraw-Hill Companies Inc., 1999.

10. Brooks GF, Carroll KC, Buthel JS, Morse $\mathrm{S}$, Mietzner T. JawetzMelnick\&Adelberg's Medical Microbiology. 26th ed., New York: The McGraw Hill Companies Inc., 2013.
11. Dwiprahasto I. Masalah penggunaan antibiotika dalam praktek. Seminar Nasional Antibiotic Update. Yogyakarta: Fakultas Kedokteran UGM, 2009.

12. Claud DT. Appendicitis. In: Ascraft KW, Murphy JP, Sharp RJ, Sigalet. DL, Snyder CL, editors. Pediatric surgery, 2nd ed. New York: W.B Saunders Company, 1993.

13. HartmanGE. Acuteappendicitis.In: Behrman RE, Kliegman RM, Jenson HB, editors. Nelson textbook of pediatrics, 17th ed. New York: WBSaunders Company, 2004.

14. Aribowo H Uji kepekaan kuman aerob pada apendisitis akut di RSUP DR. Sardjito [Tesis]. Yogyakarta: Bagian Ilmu Bedah, Fakultas Kedokteran UGM, 2001.

15. Schwart SI. Appendix. In: Schwartz SI, Ellis $\mathrm{H}$, Husser WC, editors. Maingot's Abdominal Operation, 9th ed. Norwalk, CT: Appleton and Lange, 1989.

16. Emil S, Laberge JM, Mikhail P, Baican L, Flageole H, Nguyen L, Shaw K. Appendicitis in children: a ten-year update of therapeutic recommendations. J PediatrSurg, 2003; 38(2):236-42. http://dx.doi.org/10.1053/jpsu. 2003.50052

17. Baskoro BA. Biakan dan uji sensitivitas bakteri pada peritonitis di RSUP DR. Sardjito [Tesis]. Yogyakarta: Bagian Ilmu Bedah, Fakultas Kedokteran UGM, 2005.

18. Donald M, Aaron A, Gerald G. Oral antibiotics in the management of perforated appendicitis in children. Am Surg 2002; 68(12):10724.

19. Henry MCW and Krummel TM. Surgical infectious disease. In: Ascraft KW, Murphy JP, Sharp RJ, Sigalet. DL, Snyder CL, editors. Pediatric surgery, 4nd ed. New York: W.B Saunders Company, 2005. 